\title{
Editorial
}

\section{Public health nutrition and the environment}

This issue of Public Health Nutrition includes a variety of articles relating to environment and sustainability. Last month, in an editorial for this journal, Barrie Margetts posed these questions, among others, in preparation for the World Nutrition Rio2012 Congress in April: 'Can we feed the world in an environmentally sustainable way?' and 'Can we assume that the current dominant model of global food production is environmentally sustainable?' (1).

In this issue, O'Kane ${ }^{(2)}$ asks a related question: 'What is the real cost of our food?' The real cost, in terms of social, environmental and health costs, is of course high, and O'Kane makes a strong case for supporting local food systems in order to encourage more sustainable food production methods, development of local economies and stronger ties between farmers and consumers. Her article goes further to challenge public health nutritionists to explore the potential of local food systems for reducing inequities, improving access and promoting health, to encourage people to become 'food citizens' and to advocate for sustainable food systems.

School gardens are one facet of a local food system, but without financial support success in school gardening programmes is difficult to achieve. The California Instructional School Garden Program, authorizing the distribution of \$US 15 million worth of grants towards school gardens, is one such well-intentioned effort. But as Hazzard et $a l .{ }^{(3)}$ show, in less than half of the schools receiving grants were the funds sufficient to accomplish their garden goals; over a third of schools responded that the severe budget deficit in California had a negative impact on their garden programme. School garden programmes might enjoy greater success if they are integrated into existing curricula, with active involvement by (often undervalued) home economics teachers as well as school food service personnel. If not integrated into the school curriculum, such garden programmes will continue to be viewed as external to schools' objectives and needs, and as competition for limited funding. Clearly, for local food systems to survive, they must have ongoing support and commitment from all corners: government, educators, 'food citizens' and public health practitioners.

We often think of sustainable food systems and good health as going hand in hand. Clonan et al. ${ }^{(4)}$ directly address one instance in which they are at odds - the recommendation of eating fish as an alternative to red meats - and the risk of depleting already overburdened fish stocks. They find that, in the UK, health is the primary motivation for people to eat fish, and only one out of four people think about whether the fish they buy comes from a sustainable source. Many reported confusion about the type of fish they should eat with respect to sustainability. If the increase in fish consumption continues, not just in the UK but worldwide, depletion of fish stocks becomes a too-real possibility with an unclear solution. The increase in demand for beef, pork and poultry has without question led to the unsustainable and inhumane systems we see today. Whether the demand for fish will take us to the same extreme is the question that now confronts us.

Other articles in this issue focus on a different aspect of 'environment' - food environments as determinants of dietary intake. We are pleased, for example, to have in this issue a paper describing the remarkable salt reduction programme undertaken in the UK and evidence of its success: reduced salt content of processed foods, increased consumer awareness and a decrease in the UK population's average salt intake based on urinary $\mathrm{Na}$ excretion data. Wyness et al. ${ }^{(5)}$ describe a level of collaboration among governmental and non-governmental organizations and the food industry that is impressive, unprecedented and critical to the success of such a programme. In this instance, the salt environment of the UK has been changed considerably. We eagerly await evidence of success with respect to measures of health.

At the level of the local food environment, Emond et $a l^{(6)}$ describe food availability in Latino groceries (tiendas) $v$. non-Latino supermarkets in San Diego, USA. Their study offers promising data on the positive influence of tiendas on a food environment, by offering produce that is both fresh and affordable in a low-income community. Two other studies, one conducted in Melbourne, Australia ${ }^{(7)}$ and the other in Minnesota, USA ${ }^{(8)}$, demonstrate the importance of considering the perceived food environment separately from objective measures of the food environment. We have only just begun to recognize how differently individuals perceive the food choices available to them and to understand how these perceptions affect dietary decisions. Studies addressing these issues are necessary to advance our understanding of interactions between individuals and their food environment.

In a final article to highlight in this issue, Schubert et $a l^{(9)}$ remind us of what Leitzmann and Cannon ${ }^{(10)}$ declared in this journal six years ago, as part of the New Nutrition Science: 'the main solutions to nutritional problems lie less in unlocking biological pathways, and more in creating healthy societies and also environments'. Schubert et al.'s objectives are to promote a central role for a 'social' dimension in the nutrition sciences and to encourage greater social engagement by nutrition 
researchers. But their article also provides a useful overview of how much the environmental dimension of the nutrition sciences has advanced over the past decade. The attention that we now see directed to 'the environment' in a journal of public health nutrition should surely be seen as a success on one front. Our duty is to keep the work going. In answer to Barrie Margett's initial questions: Can we assume that the current dominant model of global food production is environmentally sustainable? Clearly not. Can we feed the world in an environmentally sustainable way? Perhaps some day.

\author{
Agneta Yngve \\ Editor-in-Chief \\ Irja Haapala \\ Allison Hodge \\ Geraldine McNeill \\ Marilyn Tseng \\ Deputy Editors
}

\section{References}

1. Margetts BMM \& Rugani I (2012) How do we turn policy into action? World Nutrition Congress, Rio de Janeiro,
27-30 April 2012 (Guest Editorial). Public Health Nutr 15, $3-5$.

2. O'Kane G (2012) What is the real cost of our food? Implications for the environment, society and public health nutrition. Public Health Nutr 15, 268-276.

3. Hazzard EL, Moreno E, Beall DL et al. (2012) An evaluation of the California Instructional School Garden Program. Public Health Nutr 15, 285-290.

4. Clonan A, Holdsworth M, Swift JA et al. (2012) The dilemma of healthy eating and environmental sustainability: the case of fish. Public Health Nutr 15, 277-284.

5. Wyness LA, Butriss JL \& Stanner SA (2012) Reducing the population's $\mathrm{Na}$ intake: the UK Food Standards Agency's salt reduction programme. Public Health Nutr 15, 254-261.

6. Emond JA, Madanat HN \& Ayala GX (2012) Do Latino and non-Latino grocery stores differ in the availability and affordability of healthy food items in a low-income, metropolitan region? Public Health Nutr 15, 360-369.

7. Williams LK, Thornton L, Ball K et al. (2012) Is the objective food environment associated with perceptions of the food environment? Public Health Nutr 15, 291-298.

8. Hearst MO, Pasch KE \& Laska MN (2012) Urban $v$. suburban perceptions of the neighbourhood food environment as correlates of adolescent food purchasing. Public Health Nutr 15, 299-306.

9. Schubert L, Gallegos D, Foley W et al. (2012) Re-imagining the 'social' in the nutrition sciences. Public Health Nutr 15, 352-359.

10. Leitzmann C \& Cannon G (2005) Dimensions, domains and principles of the new nutrition science. Public Health Nutr $\mathbf{8}, 787-794$. 